\title{
Cytotoxic Compounds from the Saudi Red Sea Sponge Xestospongia testudinaria
}

\author{
Ali A. El-Gamal ${ }^{1,2}$, Shaza M. Al-Massarani ${ }^{1}$, Lamiaa A. Shaala ${ }^{3,4}$, Abdulrahman M. Alahdald ${ }^{5}$, \\ Mansour S. Al-Said ${ }^{1}$, Abdelkader E. Ashour ${ }^{6}$, Ashok Kumar ${ }^{7}$, Maged S. Abdel-Kader ${ }^{8}$, \\ Wael M. Abdel-Mageed ${ }^{1,9}$ and Diaa T. A. Youssef ${ }^{10, *}$ \\ 1 Department of Pharmacognosy, College of Pharmacy, King Saud University, P.O. Box 2457, Riyadh 11451, \\ Saudi Arabia; aelgamal00@yahoo.com or aelgamel@ksu.edu.sa (A.A.E.-G.); \\ salmassarani@ksu.edu.sa (S.M.A.-M.); msalsaid@ksu.edu.sa (M.S.A.-S.); \\ waelcognosy@yahoo.com (W.M.A.-M.) \\ 2 Department of Pharmacognosy, Faculty of Pharmacy, Mansoura University, El-Mansoura 35516, Egypt \\ 3 Natural Products Unit, King Fahd Medical Research Center, King Abdulaziz University, Jeddah 21589, \\ Saudi Arabia; lshalla@kau.edu.sa or lamiaelnady@yahoo.com \\ 4 Suez Canal University Hospital, Suez Canal University, Ismailia 41522, Egypt \\ 5 Department of Clinical Pharmacy, Faculty of Pharmacy, King Abdulaziz University, Jeddah 21589, \\ Saudi Arabia; amalahdal@kau.edu.sa \\ 6 Department of Pharmacology and Toxicology, College of Pharmacy, King Saud University, P.O. Box 2457, \\ Riyadh 11451, Saudi Arabia; aeashour@yahoo.com \\ 7 Vitiligo Research Chair, College of Medicine, King Saud University, Riyadh 11451, Saudi Arabia; \\ aknirankari@gmail.com \\ 8 Department of Pharmacognosy, College of Pharmacy, Sattam Bin Abdulaziz University, Al-kharj 11942, \\ Saudi Arabia; mpharm101@hotmail.com \\ 9 Department of Pharmacognosy, Faculty of Pharmacy, Assiut University, Assiut 71526, Egypt \\ 10 Department of Natural Products, Faculty of Pharmacy, King Abdulaziz University, Jeddah 21589, \\ Saudi Arabia \\ * Correspondence: dyoussef@kau.edu.sa; Tel.: +966-548-535-344
}

Academic Editor: Kirsten Benkendorff Received: 4 April 2016; Accepted: 21 April 2016; Published: 26 April 2016

Abstract: Bioassay-guided fractionation of the organic extract of the Red Sea sponge Xestospongia testudinaria led to the isolation of 13 compounds including two new sterol esters, xestosterol palmitate (2) and xestosterol ester of $16^{\prime}$-bromo- $\left(7^{\prime} E, 11^{\prime} E, 15^{\prime} E\right)$-hexadeca- $7^{\prime}, 11^{\prime}, 15^{\prime}$-triene- $5^{\prime}, 13^{\prime}$-diynoic acid (4), together with eleven known compounds: xestosterol (1), xestosterol ester of $18^{\prime}$-bromooctadeca- $7^{\prime} E, 9^{\prime} E$-diene- $7^{\prime}, 15^{\prime}$-diynoic acid (3), and the brominated acetylenic fatty acid derivatives, $(5 E, 11 E, 15 E, 19 E)$-20-bromoeicosa-5,11,15,19-tetraene-9,17-diynoic acid (5), 18,18-dibromo(9E)-octadeca-9,17-diene-5,7-diynoic acid (6), 18-bromooctadeca-(9E,17E)-diene-7,15-diynoic acid (7), 18-bromooctadeca-(9E,13E,17E)-triene-7,15-diynoic acid (8), 16-bromo $(7 E, 11 E, 15 E)$ hexadeca7,11,15-triene-5,13-diynoic acid (9), 2-methylmaleimide-5-oxime (10), maleimide-5-oxime (11), tetillapyrone (12), and nortetillapyrone (13). The chemical structures of the isolated compounds were accomplished using one- and two-dimensional NMR, infrared and high-resolution electron impact mass spectroscopy (1D, 2D NMR, IR and HREIMS), and by comparison with the data of the known compounds. The total alcoholic and $n$-hexane extracts showed remarkable cytotoxic activity against human cervical cancer (HeLa), human hepatocellular carcinoma (HepG-2), and human medulloblastoma (Daoy) cancer cell lines. Interestingly, the dibrominated $\mathrm{C}_{18}$-acetylenic fatty acid (6) exhibited the most potent growth inhibitory activity against these cancer cell lines followed by Compounds 7 and 9. Apparently, the dibromination of the terminal olefinic moiety has an enhanced effect on the cytotoxic activity.

Keywords: Red Sea sponge; Xestospongia testudinaria; xestosterol fatty acids esters; brominated acetylenic fatty acids; cancer cell lines; cytotoxic activity 


\section{Introduction}

Marine sponges (phylum Porifera) are among the oldest and simplest animals, which grow in every ocean and have a great capacity to withstand extreme temperatures and pressures [1]. They are filter feeders, and their bodies are full of pores and channels that allows water to circulate through them [2,3]. Moreover, they are well-known for their production of secondary metabolites that constitute an effective defense mechanism against foreign predators [2,3]. So far, about 8000 species of Porifera, inhabiting different marine and freshwater ecosystems, have been described. Since the beginning of the exploration of marine natural products in the 1970s, the investigation of the secondary metabolites of Xestospongia sponges (family Petrosiidae), commonly known as barrel sponges, have been carried out successively in several regions around the world [4]. They have been recognized as rich sources of different chemical classes, such as isoquinoline, macrocyclic quinolizidines, pyridoacridine alkaloids, quinones, sterols, brominated polyacetylenic acids, and esters [4]. Previous investigations on the chemistry and pharmacology of genus Xestospongia have shown that its crude extracts and isolated compounds displayed remarkable bioactivities, such as anti-inflammatory, antioxidant, immunomodulatory, cytotoxicity, antimicrobial, insecticidal, HIV protease inhibition, cardiotonic, vasodilatation, and antiplasmodial activities [5-9]. The currently investigated species, Xestospongia testudinaria, has been the source of indole alkaloids, sterols, sterol esters, and brominated polyunsaturated fatty acids (BPUFAs) $[4,10,11]$.

As part of our continued interest in identifying potential marine-derived bioactive compounds for treatment of contemporary diseases such as cancer and infectious diseases [12-15], we thoroughly investigated the chemical constituents and cytotoxic activity of the Red Sea sponge Xestospongia testudinaria. In this paper, we report about the purification and identification of thirteen compounds including two new xestersterol esters ( 2 and 4$)$ with eleven known compounds. In addition, the cytotoxic activities of the compounds against three cancer cell lines will be evaluated.

\section{Results and Discussion}

Compound 2 (Figure 1) was isolated as a white powder. Its HREIMS displayed [M] ${ }^{+}$at 664.6158 consistent with the molecular formula $\mathrm{C}_{46} \mathrm{H}_{80} \mathrm{O}_{2}$ and seven degrees of unsaturation. The intense IR absorption band at $1735 \mathrm{~cm}^{-1}$ indicated the presence of a carbonyl ester, which was also evident from a quaternary carbon signal, in ${ }^{13} \mathrm{C}$ NMR, at $172.1 \mathrm{ppm}$ (Tables 1 and 2). The ${ }^{13} \mathrm{C}$ NMR data of 2 (Table 1) possesses the signals for a basic steroid nucleus with 30 carton atoms (xestosterol type) as established by the similarity of its ${ }^{1} \mathrm{H}$ and ${ }^{13} \mathrm{CNMR}$ data with those of xestosterol (1) [16]. The significant differences between Compounds 1 and 2 lie in the downfield shift of $\mathrm{H}-3 / \mathrm{C}-3$ from $\delta_{\mathrm{H} / \mathrm{C}}$ $3.53 / 71.8$ in 1 to $\delta_{\mathrm{H} / \mathrm{C}} 4.55 / 73.6$ in $\mathbf{2}$, and an upfield shift of C-4 from $\delta_{\mathrm{C}} 42.2 \mathrm{ppm}$ in 1 to $\delta_{\mathrm{C}} 38.2 \mathrm{ppm}$ in 2. These differences, together with the presence of a carbonyl ester signal at $\delta_{\mathrm{C}} 172.1 \mathrm{ppm}$ in 2 , suggested the esterification of 2 at C-3. Based on evidence obtained from HR-EI-MS, ${ }^{1} \mathrm{H}$, and ${ }^{13} \mathrm{C}$ NMR (Tables 1 and 2), the ester moiety at C-3 was determined to be a long chain fatty acid (palmitic acid) [17]. The ${ }^{13} \mathrm{C}$ NMR and DEPT experiments revealed the presence of a total of 46 carbons ascribed as 30 carbons for the xestosterol skeleton, while the remaining 16 carbons were assigned to the long chain fatty acid moiety. The ${ }^{1} \mathrm{HNMR}$ spectrum (Table 2 ) showed a signal at $\delta_{\mathrm{H}} 0.79$, assigned to the terminal methyl of the long chain fatty acid, beside a long chain methylene at $\delta_{\mathrm{H}} 1.29$ integrated for 22 protons. The terminal methyl carbon appeared, in ${ }^{13} \mathrm{CNMR}$, at $\delta_{\mathrm{C}} 14.1 \mathrm{ppm}$, while the methylene carbons of the long chain moiety appeared at $\delta_{C} 34.4,25.1,31.9$, and 22.7, assigned to C-2', C-3', C-14', and $\mathrm{C}-15^{\prime}$, respectively, and from 29.1 to $29.8\left(11 \mathrm{CH}_{2}\right)$ for $\mathrm{C}-4^{\prime}-\mathrm{C}-13^{\prime}$. The complete assignment for all protons and carbons for both the steroid nucleus and the long chain fatty acid moiety was achieved by the aid of ${ }^{1} \mathrm{H}-{ }^{1} \mathrm{H}$ COSY and HSQC experiments. A careful interpretation of the HMBC spectra allowed the final structural elucidation of 2 , whereas two and three bond correlations were observed from H-4 to C-1', C-2, C-4, C-6, and C-10; from H-2 to C-1 and C-3; from H-13' to C-14' and C-15'; and from $\mathrm{H}-2^{\prime}$ to $\mathrm{C}-1^{\prime}, \mathrm{C}-3^{\prime}$, and $\mathrm{C}-4^{\prime}$. Thus, Compound 2 was deduced as xestosterol-3 palmitate and is reported here as a new natural product. 


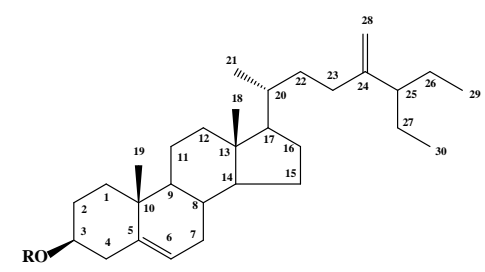

$1 \mathrm{R}=\mathrm{H}$
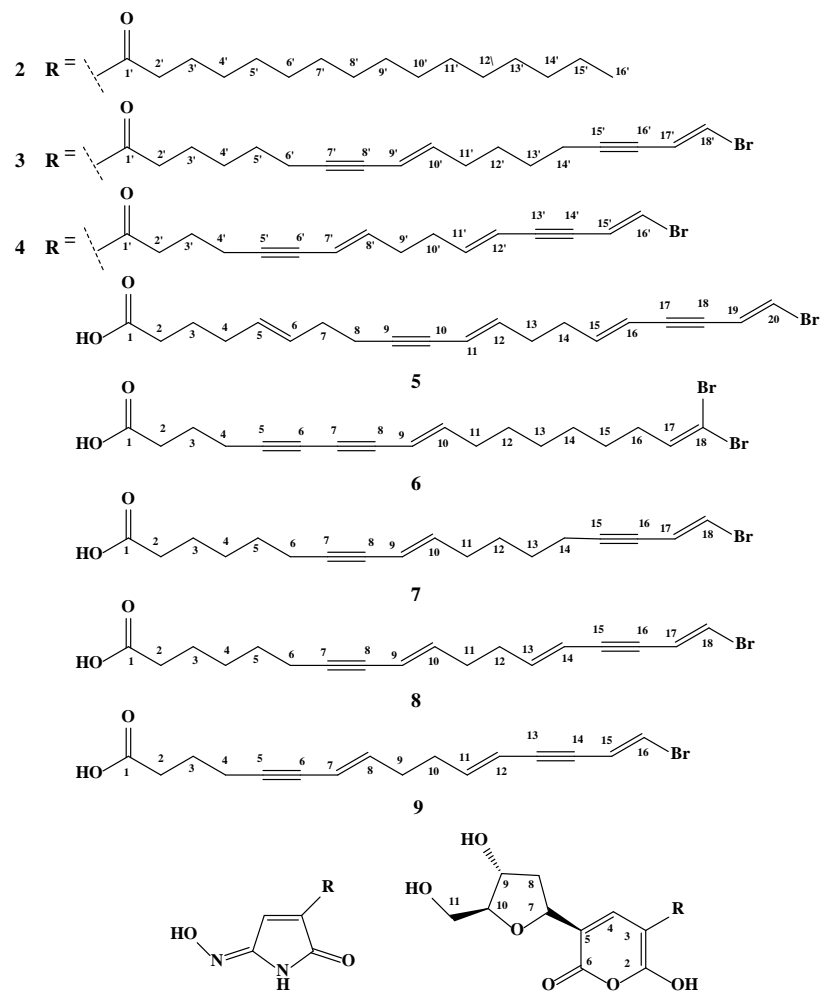

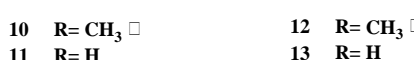

Figure 1. Structures of Compounds 1-13.

Compound 4 (Figure 1) was isolated as a yellowish brown powder. HR-FAB-MS showed [M] ${ }^{+}$ at 728.4168, consistent with the molecular formula $\mathrm{C}_{46} \mathrm{H}_{65} \mathrm{BrO}_{2}$ with 14 degrees of unsaturation. IR showed bands at 2240,1731, and $1469 \mathrm{~cm}^{-1}$, assigned to an acetylenic group, an ester group, and a terminal methylene group, respectively. The ${ }^{13} \mathrm{C}$ NMR (Table 1) and DEPT experiments showed a total of 46 carbon atoms, 30 of which were assigned to a xestosterol nucleus similar to Compounds 1-3. Xestosterol has previously been isolated and partially chemically synthesized from the same sponge [16]. On the other hand, careful analysis of the remaining 16 carbons revealed a close similarity between signals of the brominated polyacetylenic acid 9, except for the free carboxylic acid carbon $\left(\mathrm{C}-1, \delta_{\mathrm{C}}\right.$ 179.8), which was shifted to $173.1 \mathrm{ppm}$ in 4 , confirming the presence of an ester moiety. The $E$ configurations at $\mathrm{C}^{\prime} / \mathrm{C} 8^{\prime}, \mathrm{C} 11^{\prime} / \mathrm{C} 12^{\prime}$, and $\mathrm{C} 15^{\prime} / \mathrm{C} 16^{\prime}$ were secured from the large coupling constants b (15.8-16.2 Hz). Like 2, the downfield shift of $\mathrm{H}-3$, compared to 1 , and a ${ }^{3} \mathrm{~J}$ cross peak correlation, in the HMBC experiment, from H-3 $\left(\delta_{\mathrm{H}} 4.57\right)$ to $C-1^{\prime}$ (ester carbonyl at $\left.\delta_{\mathrm{C}} 173.1\right)$ justified the esterification's being at position three. Additional cross peak correlations were observed in the HMBC experiment from H-1 to C-3, C-5, and C-19. The above data proved that Compound 4 is a new ester of xestosterol-3-(16'-bromo- $7^{\prime} E, 11^{\prime} E, 15^{\prime} E$-hexadeca- $7^{\prime}, 11^{\prime}, 15^{\prime}$-triene- $5^{\prime}, 13^{\prime}$-diynoic acid) isolated here for the first time from a natural source. It is worth mentioning that xestosterol esters with brominated acetylenic fatty acid moieties have rare occurrences in marine sponges with few published reports $[10,11,18]$. 
Table 1. ${ }^{13} \mathrm{C}$ NMR data of Compound $\mathbf{1}$ and steroid part of Compounds $2-\mathbf{4}\left(125 \mathrm{MHz}, \mathrm{CDCl}_{3}\right)$.

\begin{tabular}{|c|c|c|c|c|}
\hline \multirow{2}{*}{ Position } & \multicolumn{4}{|c|}{$\delta_{C}$} \\
\hline & 1 & 2 & 3 & 4 \\
\hline 1 & 37.3 & 37.1 & 37.0 & 37.0 \\
\hline 2 & 28.2 & 28.2 & 28.2 & 28.2 \\
\hline 3 & 71.8 & 73.6 & 73.7 & 73.8 \\
\hline 4 & 42.2 & 38.2 & 38.2 & 38.2 \\
\hline 5 & 140.7 & 138.6 & 139.7 & 139.7 \\
\hline 6 & 121.7 & 122.5 & 122.6 & 122.6 \\
\hline 7 & 31.5 & 31.9 & 31.9 & 31.9 \\
\hline 8 & 31.9 & 32.8 & 31.9 & 31.9 \\
\hline 9 & 50.2 & 50.2 & 50.2 & 50.2 \\
\hline 10 & 35.8 & 36.1 & 36.6 & 36.6 \\
\hline 11 & 21.1 & 21.1 & 21.0 & 21.0 \\
\hline 12 & 39.8 & 39.7 & 39.7 & 39.7 \\
\hline 13 & 42.4 & 41.3 & 42.3 & 42.3 \\
\hline 14 & 56.8 & 56.7 & 56.7 & 56.7 \\
\hline 15 & 24.3 & 24.3 & 24.3 & 24.3 \\
\hline 16 & 29.4 & 29.4 & 29.3 & 29.3 \\
\hline 17 & 56.0 & 56.0 & 56.0 & 56.0 \\
\hline 18 & 11.9 & 11.9 & 11.9 & 11.9 \\
\hline 19 & 19.4 & 19.3 & 19.3 & 19.3 \\
\hline 20 & 35.8 & 35.8 & 35.8 & 35.8 \\
\hline 21 & 18.8 & 18.8 & 18.8 & 18.8 \\
\hline 22 & 34.4 & 34.4 & 34.5 & 34.4 \\
\hline 23 & 31.5 & 31.4 & 31.9 & 31.9 \\
\hline 24 & 152.6 & 151.3 & 152.5 & 152.6 \\
\hline 25 & 50.1 & 50.0 & 50.0 & 50.0 \\
\hline 26 & 26.4 & 26.5 & 26.3 & 26.4 \\
\hline 27 & 26.3 & 26.3 & 26.4 & 26.3 \\
\hline 28 & 108.8 & 108.9 & 108.8 & 108.8 \\
\hline 29 & 12.0 & 12.0 & 12.0 & 12.0 \\
\hline 30 & 12.1 & 12.1 & 12.1 & 12.0 \\
\hline
\end{tabular}

Table 2. Partial ${ }^{1} \mathrm{HNMR}$ data of $\mathbf{2}$ and 4 and ${ }^{13} \mathrm{C}$ NMR data of fatty acids moieties of 2-9.

\begin{tabular}{|c|c|c|c|c|c|c|c|c|c|c|}
\hline Position & \multicolumn{2}{|c|}{$\delta_{\mathrm{H}}(\mathrm{m}, J$ in $\mathrm{Hz})$} & \multicolumn{8}{|c|}{$\delta_{C}$} \\
\hline $1^{\prime}$ & & & 172.1 & 173.0 & 173.1 & 179.5 & 179.5 & 180.4 & 180.2 & 179.8 \\
\hline $3^{\prime}$ & $1.60(\mathrm{~m})$ & $1.85(\mathrm{~m})$ & 25.1 & 24.6 & 24.3 & 23.4 & 23.2 & 24.2 & 24.2 & 23.6 \\
\hline $4^{\prime}$ & $1.29(\mathrm{~m})$ & $2.39(t, 6.0)$ & 29.1 & 28.0 & 18.8 & 28.9 & 18.9 & 27.9 & 27.9 & 18.7 \\
\hline $5^{\prime}$ & $1.29(\mathrm{~m})$ & & 29.3 & 27.8 & 89.1 & 132.7 & 81.9 & 27.7 & 27.7 & 87.6 \\
\hline $7^{\prime}$ & $1.29(\mathrm{~m})$ & $5.42(\mathrm{~d}, 15.8)$ & 29.7 & 92.7 & 111.0 & 38.7 & 72.8 & 88.5 & 88.9 & 110.8 \\
\hline $8^{\prime}$ & $1.29(\mathrm{~m})$ & $5.95(\mathrm{~m})$ & 29.8 & 79.2 & 141.2 & 18.6 & 74.4 & 79.3 & 79.1 & 141.8 \\
\hline $9^{\prime}$ & $1.29(\mathrm{~m})$ & $2.22(\mathrm{~m})$ & 29.8 & 110.3 & 32.5 & 87.2 & 108.6 & 110.3 & 110.3 & 32.4 \\
\hline $10^{\prime}$ & $1.29(\mathrm{~m})$ & $2.22(\mathrm{~m})$ & 29.8 & 142.5 & 31.9 & 79.7 & 148.3 & 142.6 & 142.6 & 31.9 \\
\hline $11^{\prime}$ & $1.29(\mathrm{~m})$ & $6.10(\mathrm{~m})$ & 29.6 & 32.4 & 144.3 & 110.7 & 33.0 & 32.4 & 31.9 & 144.3 \\
\hline $12^{\prime}$ & $1.29(\mathrm{~m})$ & $5.55(\mathrm{dd}, 15.9,1.5)$ & 29.4 & 28.5 & 110.0 & 141.9 & 28.7 & 28.4 & 32.5 & 110.0 \\
\hline $16^{\prime}$ & $0.80(t, 6.9)$ & $5.60(\mathrm{~d}, 14.0)$ & 14.1 & 77.3 & 117.8 & 110.0 & 33.2 & 77.5 & 84.9 & 117.8 \\
\hline $17^{\prime}$ & & & & 117.9 & & 90.4 & 138.8 & 117.9 & 117.7 & \\
\hline $18^{\prime}$ & & & & 117.1 & & 84.9 & 88.6 & 117.1 & 117.5 & \\
\hline $19^{\prime}$ & & & & & & 117.7 & & & & \\
\hline $20^{\prime}$ & & & & & & 117.9 & & & & \\
\hline
\end{tabular}


Using a combination of 1D, 2D NMR spectra (Tables 1 and 2) and HREIMS determinations and by comparing their spectral data with those in the literature, the known compounds were identified as xestosterol (24-methylene,26,27-dimethylcholest-5-en-3 $\beta$-ol) (1) [16], xestosterol ester of $18^{\prime}$-bromo- $9^{\prime} E, 17^{\prime} E$-octadecadiene- $7^{\prime}, 15^{\prime}$-diynoic acid (3) [10], (5E,11E,15E,19E)-20bromoeicosa-5,11,15,19-tetraene-9,17-diynoic acid (5) [19], 18,18-dibromo-9E-octadeca-9,17-diene-5,7diynoic acid (6) [20], 18-bromooctadeca-9E,17E-diene-7,15-diynoic acid (7) [21], 18-bromooctadeca9E,13E,17E-triene-7,15-diynoic acid (8) [11], 16-bromo-7E,11E,15E-hexadeca-7,11,15-triene-5,13-diynoic acid (9) [20], 2-methyl maleimide-5-oxime (10) [22], maleimide-5-oxime (11) [23], tetillapyrone (12) [24], and nortetillapyrone (13) (Figure 1) [24].

The isolated compounds were evaluated for their antitumor activity against three cancer cell lines-human hepatocellular carcinoma (HepG-2), human medulloblastoma (Daoy), and human cervical cancer (HeLa) cells-using an MTT assay, as described previously [25], using dasatinib as a positive reference drug. Five concentrations $(0-50 \mu \mathrm{g} / \mathrm{mL})$ of each compound were prepared and incubated with each cell line, and the survival fraction curves were obtained to calculate the concentration that produced $50 \%$ cell growth inhibition $\left(\mathrm{IC}_{50}\right)$.

As shown in Table 3, the total ethanolic extract of X. testudinaria, $n$-hexane fraction, and Compound 6 exhibited broad spectrum inhibition of all tested cancer cell lines. In this context, the potency can be arranged in the following descending order: Compound $\mathbf{6}>n$-hexane fraction $>$ the total ethanolic extract on human cervical cancer (HeLa) and Daoy cells, while on HepG-2 cells, $\mathbf{6}>$ the total ethanolic extract $>n$-hexane fraction. Compounds 7 and $\mathbf{9}$ showed moderate selectivity against HeLa and Daoy cells. Compound 7 was more potent than $\mathbf{9}$, since the $\mathrm{IC}_{50}$ of 7 was 30.38 and $23.1 \mu \mathrm{g} / \mathrm{mL}$ on HeLa and Daoy cells, respectively, compared to 9 , which exhibited IC $_{50}$ values of 44.41 and $24.57 \mu \mathrm{g} / \mathrm{mL}$ on HeLa and Daoy cells, respectively. With regard to the sensitivity of cancer cells to the compounds, the Daoy cell line appeared to be the most sensitive towards the tested compounds, followed by HepG-2 and HeLa cell lines. Structure-activity relationships are proposed by comparing the $\mathrm{IC}_{50}$ values of the isolated brominated polyacetylenic fatty acids. The results suggest that the cytotoxic activity was dramatically enhanced by the presence of an extra bromine atom as in Compound 6 .

Table 3. Cytotoxic activity of X. testudinaria extracts and isolated compounds ${ }^{1}$.

\begin{tabular}{|c|c|c|c|c|c|c|}
\hline \multirow{2}{*}{ Test Sample } & \multicolumn{2}{|c|}{ HeLa Cell } & \multicolumn{2}{|c|}{ HepG-2 } & \multicolumn{2}{|c|}{ Daoy } \\
\hline & $\%$ Inhibition $^{2}$ & $\mathrm{IC}_{50}{ }^{3}$ & $\%$ Inhibition $^{2}$ & $\mathrm{IC}_{50}{ }^{3}$ & $\%$ Inhibition $^{2}$ & $\mathrm{IC}_{50}{ }^{3}$ \\
\hline EtOH extract & 83.35 & 35.07 & 91.24 & 23.45 & 91.6 & 23.31 \\
\hline $\begin{array}{c}\mathrm{DCM}+ \\
n-\mathrm{BuOH}\end{array}$ & 36.45 & $\mathrm{NT}^{4}$ & 8.37 & $\mathrm{NT}^{4}$ & 36.45 & $\mathrm{NT}^{4}$ \\
\hline$n$-Hexane & 91.28 & 33.7 & 89.31 & 30.2 & 90.5 & 20.74 \\
\hline 1 & 35.78 & $\mathrm{NT}^{4}$ & 46.25 & $\mathrm{NT}^{4}$ & 34.07 & $\mathrm{NT}^{4}$ \\
\hline 2 & 7.98 & $\mathrm{NT}^{4}$ & 14.72 & $\mathrm{NT}^{4}$ & 0 & $\mathrm{NT}^{4}$ \\
\hline 5 & 4.17 & $\mathrm{NT}^{4}$ & 2.09 & $\mathrm{NT}^{4}$ & 0 & $\mathrm{NT}^{4}$ \\
\hline 6 & 87.98 & 23.85 & 89.33 & 17.72 & 87.02 & 15.72 \\
\hline 7 & 67 & 30.38 & 18.4 & $\mathrm{NT}^{4}$ & 77.56 & 23.1 \\
\hline 9 & 58.61 & 44.41 & 45.23 & $\mathrm{NT}^{4}$ & 71.58 & 24.57 \\
\hline Dasatinib & 56.4 & 16.22 & 89.67 & 6.91 & 90.36 & 9.2 \\
\hline
\end{tabular}

${ }^{1}$ Compounds 10-13 were evaluated before and were weakly cytotoxic, while 3, 4, and 8 were not tested due to lack of materials. ${ }^{2}$ The percent of cell survival inhibition at $50 \mu \mathrm{g} / \mathrm{mL}$, compared to control. ${ }^{3} \mathrm{IC}_{50 \mathrm{~s}}$ are expressed in $(\mu \mathrm{g} / \mathrm{mL}) .{ }^{4}$ NT: Not tested. HeLa: human cervical cancer; HepG-2: human hepatocellular carcinoma; Daoy: human medulloblastoma.

With regard to the brominated compounds (5, 6, 7 and 9), the dibrominated compound (6) showed stronger cytotoxic activity than the monobrominated ones. On the other hand, the presence of a conjugated triple bond in Compound $\mathbf{6}$ may have contributed to the improved activity. 


\section{Materials and Methods}

\subsection{General Experimental Procedure}

The IR spectra were recorded on JASCO 320-A spectrometers, while the ${ }^{1} \mathrm{H}$ and ${ }^{13} \mathrm{C}$ NMR spectra were recorded at the NMR Unit at the College of Pharmacy, Prince Sattam Bin Abdulaziz University, on an Ultra Shield Plus $500 \mathrm{MHz}$ (Bruker) spectrometer operating at $500 \mathrm{MHz}$ for proton and $125 \mathrm{MHz}$ for carbon, respectively. The chemical shift values are reported in $\delta(\mathrm{ppm})$ relative to the TMS as an internal standard. 2D-NMR experiments (COSY, HSQC, HMBC, and NOESY) were obtained using a standard Bruker program. A HR-EI-MS, JEOL JMS-700, was used for accurate mass determination. Electron impact mode of ionization was used, keeping ionization energy at $70 \mathrm{ev}$. Resolution was set up to $10 \mathrm{k}$. A direct probe was used with a temperature ramp setting - an initial temperature of $50^{\circ} \mathrm{C}$, rising at a rate of $32^{\circ} \mathrm{C}$ per minute, and a final temperature set up to $350{ }^{\circ} \mathrm{C}$. Pre-coated silica gel TLC plates were used. The absorbance was read on a microplate reader (ELX 800, Bio-Tek Instruments, Winooski, VT, USA) at $549 \mathrm{~nm}$. MTT (3-(4,5-dimethylthiazol-2-yl)-2,5-diphenyltetrazolium bromide) was acquired from Sigma Aldrich (St Louis, MO, USA). DMEM/high glucose FBS and penicillin/streptomycin were purchased from Thermo Fisher Scientific. (Waltham, MA, USA).

\subsection{Animal Material}

The sponge was collected by hands using SCUBA diving from Ghurab Reef in the Red Sea at Jazan, Saudi Arabia between 15 and 30 meters in May 2013. The sponge was frozen immediately after collection and then freeze-dried to provide the dry material.

The sponge was identified as Xestospongia testudinaria by Prof. Rob van Soest at the Naturalis Biodiversity Center at Leiden in The Netherlands. A sample of the sponge is reserved in the collections of the Naturalis Biodiversity Center under the number RMNH Por. 9176. Another voucher specimen was placed in the Red Sea Marine Invertebrates Collection, Faculty of Pharmacy, King Abdulaziz University under the code No. DY-KSA-12. A complete description of the sponge has been previously published [5].

\subsection{Extraction and Isolation}

The freeze-dried sponge $(750 \mathrm{~g})$ was extracted with $96 \%$ ethanol $(3 \times 2 \mathrm{~L})$ at room temperature. The combined alcohol extracts were filtered and evaporated under reduced pressure using a rotatory evaporator at $38^{\circ} \mathrm{C}$ to produce $115 \mathrm{~g}$ of the alcohol extract. When methanol (500 mL) was added to the dried ethanolic extract, a precipitate was formed and collected $(26 \mathrm{~g})$. Part of this precipitate was washed repeatedly with different organic solvents to yield a pure compound (1). The other part was applied over a silica gel column with $n$-hexane/acetone in gradient elution mode to yield Compounds 2-4. On the other hand, the methanol soluble part of the ethanolic extract (88 g) was suspended in $40 \%$ ethanol (1 L) and successively partitioned with 500-mL portions of $n$-hexane, dichloromethane, and $n$-butanol to afford the corresponding fractions.

The $n$-hexane fraction $(19 \mathrm{~g})$ was chromatographed on a silica gel column $(35 \mathrm{~mm}$ i.d. $\times 350 \mathrm{~mm})$ and eluted with a $n$-hexane/acetone gradient. TLC monitoring allowed the constitution of 3 main fractions (A-C). Fraction A, eluted by $10 \%$ acetone, was chromatographed on a Sephadex LH-20 column using $10 \% \mathrm{H}_{2} \mathrm{O} / \mathrm{MeOH}$ for elution to afford both 7 and 8; Fraction $\mathrm{B}$ was subjected to a RP 18 column with gradient $\mathrm{H}_{2} \mathrm{O} / \mathrm{CH}_{3} \mathrm{CN}$ elution to yield three subfractions (I-III). Direct crystallization of subfraction II afforded $9\left(20 \% \mathrm{H}_{2} \mathrm{O} / \mathrm{CH}_{3} \mathrm{CN}\right)$. Subfraction I and III eluted by $30 \% \mathrm{H}_{2} \mathrm{O}$ was further purified separately by chromatotron (Harrison Research, Palo Alto, California, CA, USA) (centrifugal TLC) (silica gel 60, 0.04-0.06 mm, $1 \mathrm{~mm}$ using $\mathrm{MeOH} / \mathrm{CHCl}_{3}$ solvent system, to give 5 and $\mathbf{6}$.

The $\mathrm{CH}_{2} \mathrm{Cl}_{2}(1.5 \mathrm{~g})$ and $n$ - $\mathrm{BuOH}(2.2 \mathrm{~g})$ fractions were combined due to the similarity on TLC, part of which $(0.9 \mathrm{~g})$ was further purified by column chromatography using a $\mathrm{MeOH} / \mathrm{DCM}$ gradient to give, after TLC examination, five fractions (1-5). Fractions 1, 2, and 3 eluted with $2 \% \mathrm{MeOH} / \mathrm{CH}_{2} \mathrm{Cl}_{2}$ yielded, after further purification, Compounds 10-12, respectively. Fraction 4, also eluted with 
$2 \% \mathrm{MeOH} / \mathrm{CH}_{2} \mathrm{Cl}_{2}$, was separately purified by chromatotron using $12 \% \mathrm{MeOH} / \mathrm{CH}_{2} \mathrm{Cl}_{2}$ to give Compound 13.

\subsection{Spectral Data of the Compounds}

Xestosterol palmitate (2). White powder; HR-EI-MS m/z $664.6158[\mathrm{M}]^{+}$for $\mathrm{C}_{46} \mathrm{H}_{80} \mathrm{O}_{2}$; IR (KBr) $v_{\max }$ 2934, 2867, 2212, 2190, 1734, 1463, 956, $886 \mathrm{~cm}^{-1} .{ }^{1} \mathrm{H}$ NMR $\left(\mathrm{CDCl}_{3}, 500 \mathrm{MHz}\right): \delta_{H} 1.05,1.71(1 \mathrm{H}$ each, $\mathrm{m}, \mathrm{H}-1), 1.58,1.76$ (1H each, m, H-2), 4.45, (1H, m, H-3), $2.48(2 \mathrm{H}, \mathrm{br} \mathrm{t}, J=12 \mathrm{~Hz}, \mathrm{H}-4), 5.33(1 \mathrm{H}$, br s, H-6), 1.36, 1.92 (1H each, m, H-7), 1.46 (1H, m, H-8), 0.90 (1H, m, H-9), 1.45 (2H, m, H-11), 1.18, 2.07 (1H each, m, H-12), 0.96 (1H, m, H-14), 1.07, 1.56 (1H, m, H-15), 1.31, 1.89 (1H each, m, H-16), 1.15 (1H, $\mathrm{m}, \mathrm{H}-17), 0.67$ (3H, s, H-18), 1.01(3H, s, H-19), $1.47(1 \mathrm{H}, \mathrm{m}, \mathrm{H}-20), 0.97,(3 \mathrm{H}, \mathrm{d}, J=7.5 \mathrm{~Hz}, \mathrm{H}-21), 1.37$, $1.79(2 \mathrm{H}, \mathrm{m}, \mathrm{H}-22), 1.98,2.19$ (2H, m, H-23), 1.89 (1H, m, H-25), 1.47 (2H, m, H-26), 1.46 (2H, m, H-27), $4.65,4.73\left(2 \mathrm{H}\right.$, br s, H-28), 0.82, $(3 \mathrm{H}, \mathrm{t}, J=7.3 \mathrm{~Hz}, \mathrm{H}-29), 0.82(3 \mathrm{H}, \mathrm{t}, J=7.3 \mathrm{~Hz}, \mathrm{H}-30),{ }^{1} \mathrm{HNMR}$ of side chain fatty acid: see Table $2,{ }^{13} \mathrm{CNMR}$ : see Table 1 .

Xestosterol ester of 16-bromo-7E,11E,l5E-hexadeca-7,11,15-triene-5,13-diynoic acid (4). Yellowish brown powder; HR-FAB-MS $m / z 728.4168[\mathrm{M}]^{+}$for $\mathrm{C}_{46} \mathrm{H}_{65} \mathrm{BrO}_{2}$. IR (KBr) $v_{\max } 2240,1731,1469 \mathrm{~cm}^{-1}$. ${ }^{1} \mathrm{H}$ NMR $\left(\mathrm{CDCl}_{3}, 500 \mathrm{MHz}\right): \delta_{H} 4.57(1 \mathrm{H}, \mathrm{m}, \mathrm{H}-3), 4.57(1 \mathrm{H}, \mathrm{d}, J=0.9 \mathrm{~Hz}, \mathrm{H}-6), 0.65(3 \mathrm{H}, \mathrm{s}, \mathrm{H}-18), 0.99,(3 \mathrm{H}, \mathrm{s}$, $\mathrm{H}-19), 0.91,(3 \mathrm{H}, \mathrm{d}, J=6.5 \mathrm{~Hz}, \mathrm{H}-21), 4.65,4.72$ (2H, br s, H-28), 0.76, (3H, t, J = 7.3 Hz, H-29), 0.76 (3H, $\mathrm{t}, J=7.3 \mathrm{~Hz}, \mathrm{H}-30) .{ }^{1} \mathrm{HNMR}$ of side chain fatty acid: see Table $2,{ }^{13} \mathrm{CNMR}$ : see Table 1.

2-Methyl maleimide-5-oxime (10). ${ }^{13} \mathrm{CNMR}$ (DMSO- $d_{6}, 125 \mathrm{MHz}$ ): $\delta_{\mathrm{C}} 164.93$ (CO-2), 151.47 (C-5), $137.70(\mathrm{CH}-4), 107.67$ (C-3), $11.75\left(\mathrm{CH}_{3}\right)$.

Maleimide-5-oxime (11). ${ }^{13} \mathrm{CNMR}$ (DMSO- $d_{6}$ ): $\delta_{\mathrm{C}} 164.93$ (C-2), 151.4 (C-5), 137.7 (C-4), 107.6 (C-3).

Tetillapyrone (12). ${ }^{13} \mathrm{C}$ NMR (MeOD): $\delta_{\mathrm{C}} 152.4$ (C-2), 111.6 (C-3), 138.2 (C-4), 111.6 (C-5), 166.5 (C-6), 86.3 (C-7), 41.2 (C-8), 72.2 (C-9), 88.8 (C-10), 62.7 (C-11), $12.5\left(\mathrm{CH}_{3}\right)$.

Nortetillapyrone (13). ${ }^{13} \mathrm{C}$ NMR (MeOD): $\delta_{\mathrm{C}} 152.3$ (C-2), 102.8 (C-3), 142.6 (C-4), 102.8 (C-5), 166.3 (C-6), 86.7 (C-7), 41.3 (C-8), 72.3 (C-9), 89.0 (C-10), 62.9 (C-11).

\subsection{Evaluation of the Antiproliferative Activity of the Compounds Using MTT Assay}

The three utilized tumor cell lines were human cervical cancer (HeLa), human hepatocellular carcinoma (HepG-2) and human medulloblastoma (Daoy) cells. HeLa and HepG-2 cells were cultured in DMEM/high glucose supplemented with 10\% FBS, $2 \mathrm{mM}$ of L-glutamine, and 1\% penicillin/streptomycin. Daoy cells were cultured in DMEM/F12 supplemented with 10\% FBS, $2 \mathrm{mM}$ of L-glutamine, and 1\% penicillin/streptomycin.

All isolated compounds were evaluated at the Cell Culture Laboratory, College of Pharmacy, King Saud University, in a three-cell line-one concentration $(50 \mathrm{mg} / \mathrm{mL})$ anticancer assay against the aforementioned cell lines, adapting the method described by Al-Salahi et al. 2014 [25].

The dose response curves of the compounds affecting $\geqslant 50 \%$ inhibition in one-dose prescreening for each cell line were established with concentrations of 50, 25, 12.5, 6.25, 3.125, and $1.56 \mu \mathrm{g} / \mathrm{mL}$, and the concentrations causing $50 \%$ cell growth inhibition $\left(\mathrm{IC}_{50}\right)$ were calculated. The cytotoxic activity of the anticancer drug dasatinib [26] against the tested cell lines was examined at the same concentrations of the tested compounds.

\section{Conclusions}

In conclusion, bioassay-directed fractionation of the active fractions of the organic extracts of the Red Sea sponge Xestospongia testudinaria afforded thirteen compounds including two new xestosterol esters (2 and 4) together with several known compounds (1, 2, 5-13). The identification of the compounds was achieved by analysis of the NMR and MS data of the compounds and by comparison with the literature. The compounds showed different cytotoxic activities towards the three tested cancer cell lines. 
Acknowledgments: The authors extend their appreciation to the Deanship of Scientific Research at King Saud University for funding the work through the Research Group Project no. RG-1437-021. We would like to thank Rob van Soest for the taxonomic identification of the sponge material.

Conflicts of Interest: The authors declare no conflict of interest.

\section{References}

1. Sagar, S.; Kaur, M.; Minnema, K. Antiviral lead compounds from marine sponges. Mar. Drugs 2010, 8, 2619-2638. [CrossRef] [PubMed]

2. Laport, M.; Santos, O.; Muricy, G. Marine sponges: Potential sources of new antimicrobial drugs. Curr. Pharm. Biotechnol. 2009, 10, 86-105. [CrossRef] [PubMed]

3. Newman, D.; Cragg, G. Marine natural products and related compounds in clinical and advanced preclinical trials. J. Nat. Prod. 2004, 67, 1216-1238. [CrossRef] [PubMed]

4. Zhou, X.; Xu, T.; Yang, X.-W.; Huang, R.; Yang, B.; Tang, L.; Liu, Y. Chemical and biological aspects of marine sponges of the genus Xestospongia. Chem. Biodivers. 2010, 7, 2201-2227. [CrossRef] [PubMed]

5. El-Shitany, N.A.; Shaala, L.A.; Abbas, A.T.; Abdel-dayem, U.A.; Azhar, E.I.; Ali, S.S.; van Soest, R.W.M.; Youssef, D.T.A. Evaluation of the anti-inflammatory, antioxidant and immunomodulatory effects of the organic extract of the Red Sea marine sponge Xestospongia testudinaria against carrageenan induced rat paw inflammation. PLoS ONE 2015, 10, e0138917. [CrossRef] [PubMed]

6. Cerqueira, F.; Watanadilok, R.; Sonchaeng, P.; Kijjoa, A.; Pinto, M.; Quarles van Ufford, H.; Kroes, B.; Beukelman, C.; Nascimento, M. Clionasterol: A potent inhibitor of complement component C1. Planta Medica 2003, 69, 174-176. [CrossRef] [PubMed]

7. Edrada, R.; Proksch, P.; Wray, V.; Witte, L.; Müller, W.; van Soest, R. Four new bioactive manzamine-type alkaloids from the Philippine marine sponge Xestospongia ashmorica. J. Nat. Prod. 1996, 59, 1056-1060. [CrossRef] [PubMed]

8. Nakamura, M.; Kakuda, T.; Qi, J.; Hirata, M.; Shintani, T.; Yoshioka, Y.; Okamoto, T.; Oba, Y.; Nakamura, H.; Ojika, M. Novel relationship between the antifungal activity and cytotoxicity of marine-derived metabolite xestoquinone and its family. Biosci. Biotechnol. Biochem. 2005, 69, 1749-1752. [CrossRef] [PubMed]

9. Patil, A.; Kokke, W.; Cochran, S.; Francis, T.; Tomszek, T.; Westley, J. Brominated polyacetylenic acids from the marine sponge Xestospongia muta: Inhibitors of HIV protease. J. Nat. Prod. 1992, 55, 1170-1177. [CrossRef] [PubMed]

10. Pham, N.; Butler, M.; Hooper, J.; Moni, R.; Quinn, R. Isolation of xestosterol esters of brominated acetylenic fatty acids from the marine sponge Xestospongia testudinaria. J. Nat. Prod. 1999, 62, 1439-1442. [CrossRef] [PubMed]

11. Taniguchi, M.; Uchio, Y.; Yasumoto, K.; Kusumi, T.; Ooi, T. Brominated unsaturated fatty acids from marine sponge collected in Papua New Guinea. Chem. Pharm. Bull. (Tokyo) 2008, 56, 378-382. [CrossRef] [PubMed]

12. Shaala, L.A.; Youssef, D.T.A.; Badr, J.M.; Sulaiman, M.; Khedr, A.; El Sayed, K.A. Bioactive alkaloids from the Red Sea marine Verongid sponge Pseudoceratina arabica. Tetrahedron 2015, 71, 7837-7841. [CrossRef]

13. Shaala, L.A.; Youssef, D.T.A.; Badr, J.M.; Souliman, M.; Khedr, A. Bioactive secondary metabolites from a Red Sea marine Verongid sponge Suberea species. Mar. Drugs 2015, 13, 1621-1631.

14. Shaala, L.A.; Youssef, D.T.A. Identification and bioactivity of compounds from the fungus Penicillium sp. CYE-87 isolated from a marine tunicate. Mar. Drugs 2015, 13, 1698-1709. [CrossRef] [PubMed]

15. Youssef, D.T.A.; Shaala, L.A.; Alshali, K.Z. Bioactive hydantoin alkaloids from the Red Sea marine sponge Hemimycale arabica. Mar. Drugs 2015, 13, 6609-6619. [CrossRef] [PubMed]

16. Kokke, W.C.M.C.; Tarchini, C.; Stierle, D.B.; Djerassi, C. Isolation, structure elucidation and partial synthesis of xestosterol, biosynthetically significant sterol from the sponge Xestospongia muta. J. Org. Chem. 1979, 44, 3385-3388. [CrossRef]

17. Bulama, J.; Dangoggo, S.; Halilu, M.; Tsaf, A.I.; Hassan, S. Isolation and characterization of palmitic acid from ethyl acetate extract of root bark of Terminalia glaucescens. Chem. Mater. Res. 2014, 6, 140-143.

18. Ayyad, S.E.; Katoua, D.F.; Alarif, W.M.; Sobahi, T.R.; Aly, M.M.; Shaala, L.A.; Ghandourah, M.A. Two new polyacetylene derivatives from the Red Sea sponge Xestospongia sp. Z. Naturforschung C 2015, 70, 297-303.

19. Brantley, S.E.; Molinski, T.F.; Preston, C.M.; DeLong, E.F. Brominated acetylenic fatty acids from Xestospongia sp., a marine spongebacteria association. Tetrahedron 1995, 51, 7667-7672. [CrossRef] 
20. Hirsh, S.; Carmely, S.; Kashman, Y. Brominated unsaturated acids from the marine sponge Xestospongia sp. Tetrahedron 1987, 43, 3257-3261. [CrossRef]

21. Quinn, R.J.; Tucker, D.J. A brominated bisacetylenic acid from the marine sponge Xestospongia testudinaria. Tetrahedron Lett. 1985, 26, 1671-1672. [CrossRef]

22. Kijjoa, A.; Bessa, J.; Wattanadilok, R.; Sawangwong, P.; Nascimento, M.; Pedro, M.; Silva, A.; Eaton, G.; van Soest, R.; Herz, W. Dibromotyrosine derivatives, a maleimide, aplysamine-2 and other constituents of the marine sponge Pseudoceratina purpurea. Z. Naturforschung 2005, 60b, 904-908.

23. Wattanadilok, R.; Sawangwong, P.; Rodrigues, C.; Cidade, H.; Pinto, M.; Pinto, E.; Silva, A.; Kijjoa, A. Antifungal activity evaluation of the constituents of Haliclona baeri and Haliclona cymaeformis, collected from the Gulf of Thailand. Mar. Drugs 2007, 5, 40-51. [CrossRef] [PubMed]

24. Wattanadilok, R.; Sonchaeng, P.; Kijjoa, A.; Damas, A.; Gales, L.; Silva, A.; Herz, W. Tetillapyrone and nortetillapyrone, two unusual hydroxypyran-2-ones from the marine sponge Tetilla japonica. J. Nat. Prod. 2001, 64, 1056-1058. [CrossRef]

25. Al-Salahi, R.; Marzouk, M.; Ashour, A.; Alswaidan, I. Antitumor activity of 1,2,4-triazolo[1,5-a]quinazolines. Asian J. Chem. 2014, 26, 2173-2176.

26. Lombardo, L.; Lee, F.; Chen, P.; Norris, D.; Barrish, J.; Behnia, K.; Castaneda, S.; Cornelius, L.; Das, J.; Doweyko, A.; et al. Discovery of N-(2-chloro-6-methyl-phenyl)-2-(6-(4-(2-hydroxyethyl)piperazin-1-yl)-2-methylpyrimidin-4-ylamino) thiazole-5-carboxamide (BMS-354825), a dual Src/Abl kinase inhibitor with potent antitumor activity in preclinical assays. J. Med. Chem. 2004, 47, 6658-6661. [CrossRef] [PubMed]

(C) 2016 by the authors; licensee MDPI, Basel, Switzerland. This article is an open access article distributed under the terms and conditions of the Creative Commons Attribution (CC-BY) license (http://creativecommons.org/licenses/by/4.0/). 